\title{
Surface temperature of plant tissues. Which method of air temperature measurement fits best?
}

\author{
Tomáš LITSCHMANN ${ }^{1}$, Tomáš STŘEDA ${ }^{2,3}$ \\ ${ }^{1}$ AMET, \\ Žižkovská 1230, 691 02, Velké Bílovice, Czech Republic, \\ e-mail: amet@email.cz \\ ${ }^{2}$ Department of Crop Science, Breeding and Plant Medicine, Mendel University in Brno, \\ Zemědělská 1665/1, 61300 Brno, Czech Republic, \\ e-mail: streda@mendelu.cz \\ ${ }^{3}$ Department of Meteorology and Climatology, Czech Hydrometeorological Institute, \\ Brno Branch, Kroftova 43, 61667 Brno, Czech Republic
}

\begin{abstract}
Climate change is contributing to an increased risk of flower damage by late spring frosts. Monitoring flower temperature is critical for the timely start of frost protection systems. However, there are many weak points that complicate the use of this method. The aims of this study were to: i) find the method of air temperature measurement with the best relationship to the surface temperature of plant tissues and ii) quantify the differences between plant tissues surface temperature and ambient temperature during different weather situations. The surface temperature of plant tissues (budding leaves of grapevine, apricot flower, and unripe pear fruit), air temperature and humidity in the radiation shield, wet bulb temperature and air temperature with an unsheltered thermometer were measured at ten-minute intervals in the spring months. The average temperatures obtained by the individual methods as well as the lowest temperatures were determined from each measurement. Differences between air temperatures and plant surface temperatures, including variation ranges, were also determined. An unsheltered thermometer, in which the energy balance corresponds approximately to that of the evaluated plant surfaces, provided the best relationship with plant tissue temperature. The air temperature measured by the standard method (in a Stevenson screen or in the radiation shield) was almost always higher than the temperature of the plant tissue during periods of negative energy balance. The difference between the minimum temperatures was approximately $0.5^{\circ} \mathrm{C}$. Temperatures more than $1.5^{\circ} \mathrm{C}$ higher than the actual temperature of plant tissues were measured in extreme cases.
\end{abstract}

Key words: flower temperature, leaf temperature, agricultural meteorology, cold damage, frost damage, microclimate 


\section{Introduction}

Increased interest in the issue of spring frosts is caused by the bioclimatic impacts of climate change in recent decades. Current regional studies on Central Europe state that an earlier onset of the phenological phase or the "beginning of apricot flowering" occurred for approximately 13 days in the period 1940-2008, i.e., 2 days per decade (Chuchma et al., 2016). A similar result has been documented for an evaluation of long-term phenological data series of wild-growing plants (Stehnová et al., 2017; Stehnová et al., 2018). Earlier flowering increases the risk of frost damage to flowers by late spring frosts.

There are numerous methods of microclimate modification and for mitigating cold damage to horticultural crops. These include stack heaters, wind machines, helicopters, fog generators, covers, and various irrigation methods such as flooding (Morrow and Martsolf, 2004). However, the timing of the implementation of these methods depends on the precise determination and prediction of risk conditions.

It is often assumed that the temperature of plant tissues corresponds to the air temperature measured by the standard method. In one of the first complex works to evaluate the difference between carnation flower temperature and air temperature, Hanan (1965) described that the radiation, air velocity and air temperature effects were not as high as expected. This was confirmed by Hanan (1970) in follow-up research. Under certain conditions of wind velocity, solar radiation and air temperature, differentials between red carnation flower temperature and air temperature exceeded $10^{\circ} \mathrm{C}$, whereas white flowers were close to the ambient air temperature.

Some complications in predicting flower temperature are as follows:

i) The air temperature is monitored, while it is truly the plant temperature that is usually predicted from two meteorological parameters: the air temperature and an estimate of the radiational cooling (Morrow and Martsolf, 2004). Meteorological data differing from the actual conditions of canopy microclimate are often used for this purpose. Compared to the canopy microclimate, the conditions at a standard climatological station are characterized by a reduction of temperature extremes, a wetter environment with lower variability, precipitation interception, reduced air speed, occurrence of diffuse solar radiation, etc. (Středa et al., 2011). 
ii) Flower colour can significantly influence flower interior temperature due to differences in how the pigments absorb and reflect different wavelengths of light (Seymour et al., 2009; Mu et al., 2010). Mu et al. (2010) have determined the effect of petal colour on the interior temperature of Gentiana leucomelaena flowers, which have two colours (blue and white). Relative to the ambient temperature, the flower temperature was $1.27^{\circ} \mathrm{C}$ higher in the white flowers but was $0.41^{\circ} \mathrm{C}$ lower in the blue flowers. The ambient temperature was closely correlated with the flower frequency, i.e., white flowers were more likely to be associated with low temperature than blue flowers. Savvides et al. (2017) described differences of several degrees Celsius $\left(-4.1\right.$ to $\left.3.8^{\circ} \mathrm{C}\right)$ between the apical meristem temperature and air temperature in cucumber and tomato plants when the air temperature was kept at $\sim 20^{\circ} \mathrm{C}$ as a function of other environmental factors that influence the heat budget of the apical meristem such as radiation, air humidity, wind speed, and plant traits. Shrestha et al. (2018) found that the relationship between flower temperature and ambient temperature was non-significant for 4 samples, non-linear for 11 samples, linear for 3 samples and positive linear for 13 samples (30 plant species with 31 samples), and they found no significant correlation between temperature modulation type group and/or either colour or shape in our sample species.

iii) One of the more unusual tactics for promoting cross-pollination occurs in flowers that raise their temperatures by producing their own heat (Seymour and Schultze-Motel, 1997). The flowers of some plants produce enough heat to raise their temperatures by as much as tens of degrees Celsius above air temperature (by increasing heat production to approximately $1000 \mathrm{~mW}$ ). The greatest heat producer, Arum maculatum, generates 0.4 watts per gram in its florets. A 125-gram spadix of Philodendron selloum produces about nine watts of heat to maintain a temperature of $40^{\circ} \mathrm{C}$ in a $10^{\circ} \mathrm{C}$ ambient environment (Seymour, 1997). In montane forests on sunny days with very low wind speeds, meristem (not flower) temperatures can be $15{ }^{\circ} \mathrm{C}$ higher than the air temperature (Wilson et al., 1987). Analogously, a study by Little et al. (2016) found that some sub-Antarctic herbs exhibited leaf and floral temperatures that were higher than the ambient temperature (leaves and inflorescences were $9{ }^{\circ} \mathrm{C}$ and $11^{\circ} \mathrm{C}$ higher than the ambient temper- 
ature respectively).

iv) The insufficiently explored "critical temperatures" for predicting flower damage on fruit trees are another problem. As a rule, it is not clear how these temperatures were obtained. The deficiency of this concept is the fact that different types of cooling have not been taken into account (Dětinský and Havlik, 1990).

The main question addressed by this paper is which temperature measurement methodology is best for predicting and mitigating damage to crops by frost. The ideal method should be applicable for a wide range of weather situations. It should also be as close as possible to the temperature of the threatened plant tissues.

\section{Materials and methods}

The measurements were carried out during a period from the $10^{\text {th }}$ of April 2018 to the $9^{\text {th }}$ of May 2018 (Table 1) in the experimental area of Moravský Žižkov (South Moravia, Czech Republic), which has a long-term average annual air temperature of $9.2^{\circ} \mathrm{C}$, an average annual precipitation of $482 \mathrm{~mm}$, and a long-term average monthly temperature of $9.7^{\circ} \mathrm{C}$ in April and of $14.5^{\circ} \mathrm{C}$ in May. The surface temperature of the plant tissues (surface thermometer), the air temperature and air humidity in a radiation shield (sheltered thermometer and humidity meter), the wet bulb temperature with an unsheltered thermometer (thermometer covered with a wet cloth; wet temperature), and the air temperature with an unsheltered thermometer were measured at ten-minute intervals. The sensors were located at the same height in the immediate vicinity of the crop. The air temperature in the radiation shield at a standard height of $2 \mathrm{~m}$ and the wind speed at a height

Table 1. Overview of measurement dates for individual plant surfaces.

\begin{tabular}{|l|l|l|l|}
\hline Plant species & $\begin{array}{l}\text { Measured } \\
\text { surface }\end{array}$ & $\begin{array}{l}\text { Beginning of } \\
\text { measurement }\end{array}$ & $\begin{array}{l}\text { End of } \\
\text { measurement }\end{array}$ \\
\hline apricot & flower & $10^{\text {th }}$ April 2018 & $16^{\text {th }}$ April 2018 \\
\hline pear & flower & $16^{\text {th }}$ April 2018 & $22^{\text {nd }}$ April 2018 \\
\hline grapevine & leaves & $22^{\text {nd }}$ April 2018 & $1^{\text {st }}$ May 2018 \\
\hline pear & green fruit & $1^{\text {st }}$ May 2018 & $9^{\text {th }}$ May 2018 \\
\hline
\end{tabular}


of $6 \mathrm{~m}$ above the terrain were measured at a distance of several metres. The air temperature was measured with a DS18B20 sensor (Maxim Integrated, San Jose, California, USA). Air humidity was measured with a HIH-4000 sensor (Honeywell, Golden Valley, Minnesota, USA).

An infrared temperature sensor, the Omega OS211-LT, connected to a MeteoUNI data logger (AMET, Velké Bílovice, Czech Republic), was used to measure the surface temperatures of the plant tissues - Fig. 1.

The period from sunset to sunrise, when plants and unsheltered thermometers were not affected by shortwave radiation, was evaluated. Air temperature measurement in the radiation shield was chosen as the standard method of determining the air temperature. According to Snyder and de Melo-Abreuet (2005), it is advisable to use a wet bulb thermometer in situations preceded by a rainy season or intense dew. The length of time that the plant tissues are covered with dew varies overnight, but the wet bulb thermometer loses heat by evaporation permanently. Consequently, a variant with an unsheltered thermometer placed close to the measured surface was also realized. In the case of rain or dew, the presence of liquid water on its surface is similar to that of the examined tissues.

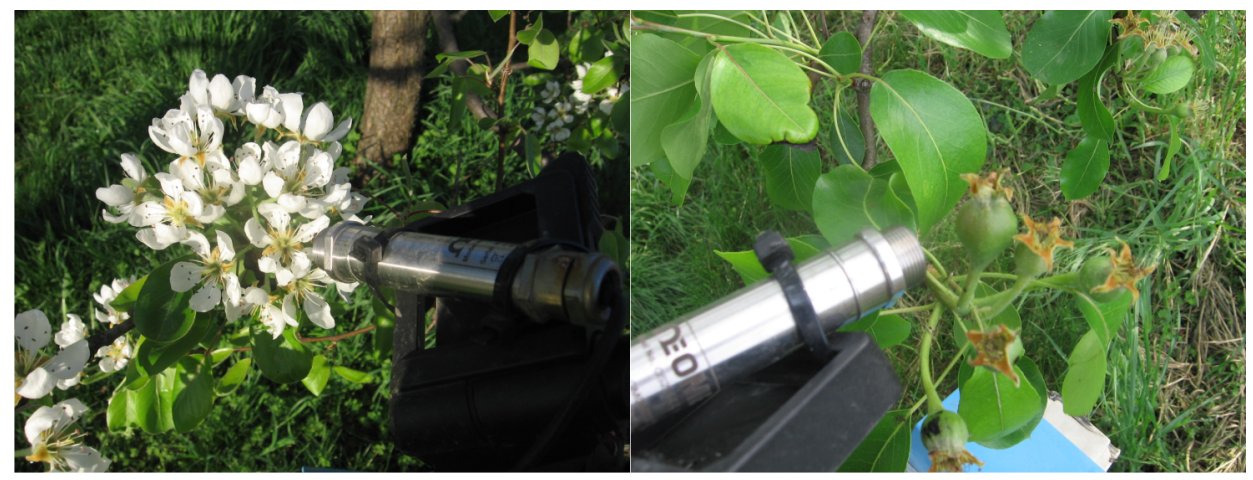

Fig. 1. Measurement of the surface temperature of plant tissues with an infrared sensor.

\section{Results and discussion}

The courses of air temperature, air humidity and the surface temperature of the budding leaf during representative weather conditions are shown in Figs. 2 and 3. Cases with low wind speeds not exceeding $0.5 \mathrm{~m} \mathrm{~s}^{-1}$ and 


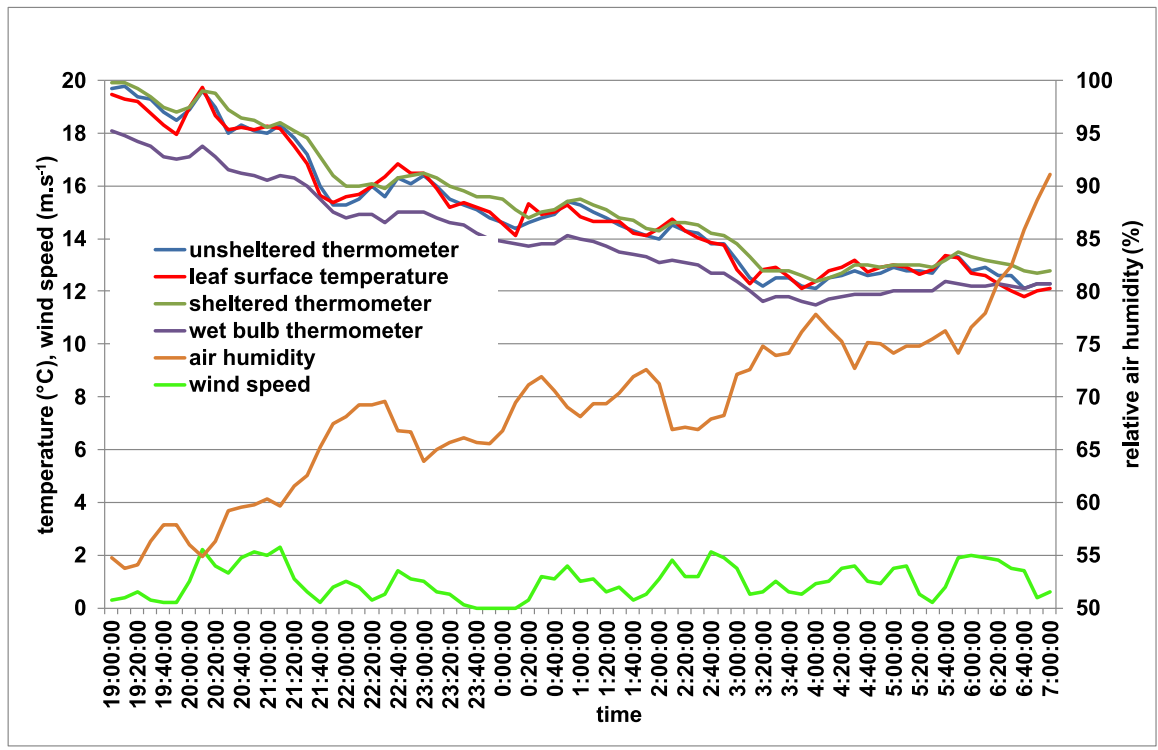

Fig. 2. The courses of air temperatures and the surface temperature of the budding leaves of grapevine on the $25-26^{\text {th }}$ of April 2018 (no wind, low air humidity).

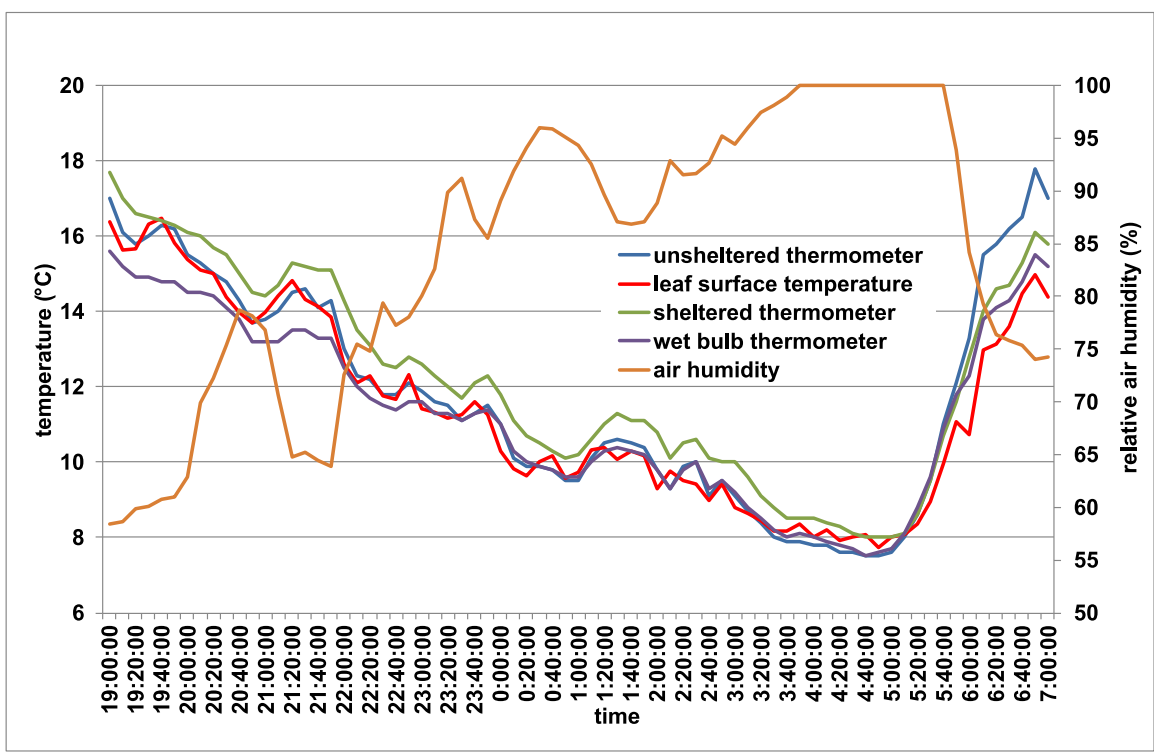

Fig. 3. The courses of air temperatures and the surface temperature of the budding leaves of grapevine on the $24-25^{\text {th }}$ of April 2018 (no wind, low air humidity). 
with varying relative air humidity have been selected. In the first case, the air humidity during the night ranged from $60-75 \%$ and only began to rise rapidly close to the morning. Therefore, the wet temperature was below the leaf surface temperature for most of this time and approached it when the humidity increased. Although the wet thermometer showed a lower value almost all night, the values were most similar when the stand temperature was low. On the other hand, the air temperature measured by the sheltered thermometer was almost always higher than the temperature of the stand and higher even when the stand temperature was at its minimum. Relatively good congruence between the unsheltered thermometer and the temperature of the crop was shown during the whole monitoring period.

The period of higher relative humidity was considerably longer in the second case. After air humidity rose above $85 \%$, all three curves (leaf temperature, wet temperature, and the temperature measured with an unsheltered thermometer) almost coincide (even when the minimum is reached). The fastest temperature increase was measured with the unsheltered thermometer after sunshine was recorded; the increase in the surface temperature of the budding leaves was lowest.

It is obvious that a good relationship can be expected between the surface temperature of plant tissues and the temperature measured with the unsheltered thermometer. For the wet thermometer, the magnitude of deviation depends on the air humidity or the occurrence of precipitation (Fig. 4). The difference between the temperature of the wet thermometer and the flower temperature was greater than $2{ }^{\circ} \mathrm{C}$ before rain. The unsheltered thermometer showed a very good relationship with the flower temperature before the rain. Its values came close to those of the wet thermometer due to moistening by the rain. The air temperature measured in the shield indicated higher values than the actual flower temperature.

Fig. 5 shows the significantly different meteorological situation that occurred the following night. The radiation character of night weather and windlessness contributed to a sharp drop in air temperatures and the surface temperatures of apricot flowers. The surface temperature of flowers during this type of weather fell to its lowest value. A similar state can be expected even when temperatures drop to or below $0{ }^{\circ} \mathrm{C}$, i.e., to a level with a risk of flower damage from frost. This course confirms the effect of the cooling character on the reaction of thermometers of various constructions. This 


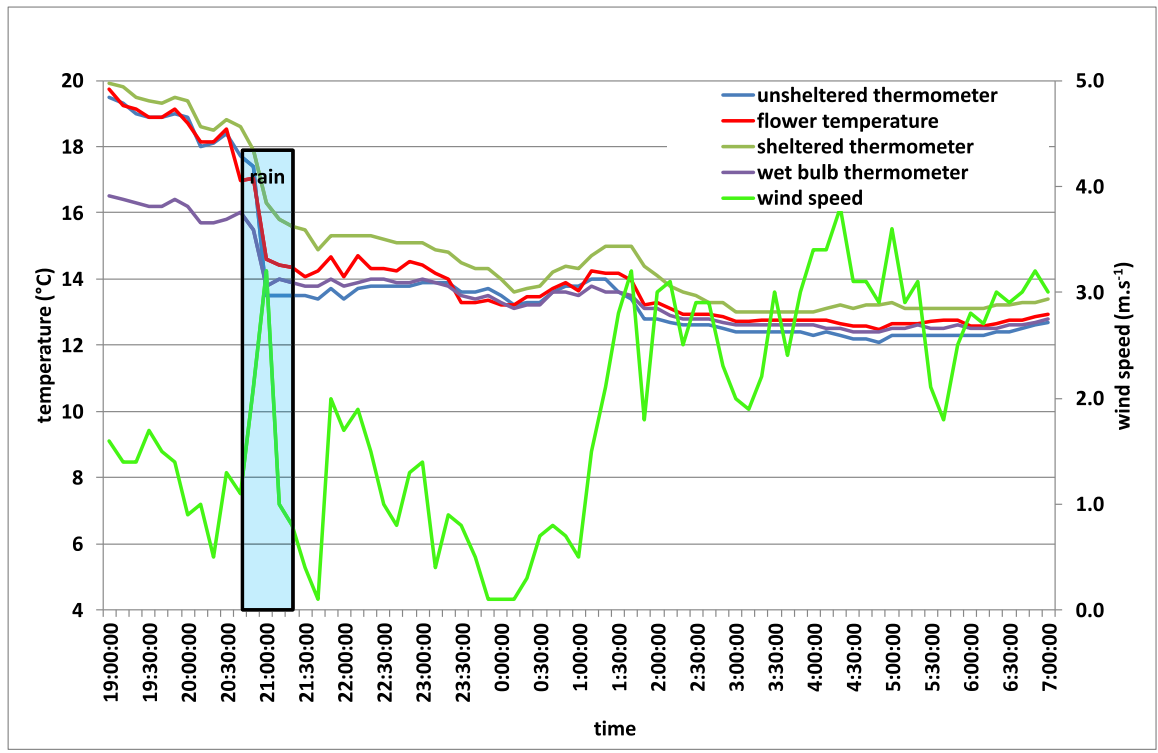

Fig. 4. The courses of air temperature and the surface temperature of the apricot flowers on the $12-13^{\text {th }}$ of April 2018.

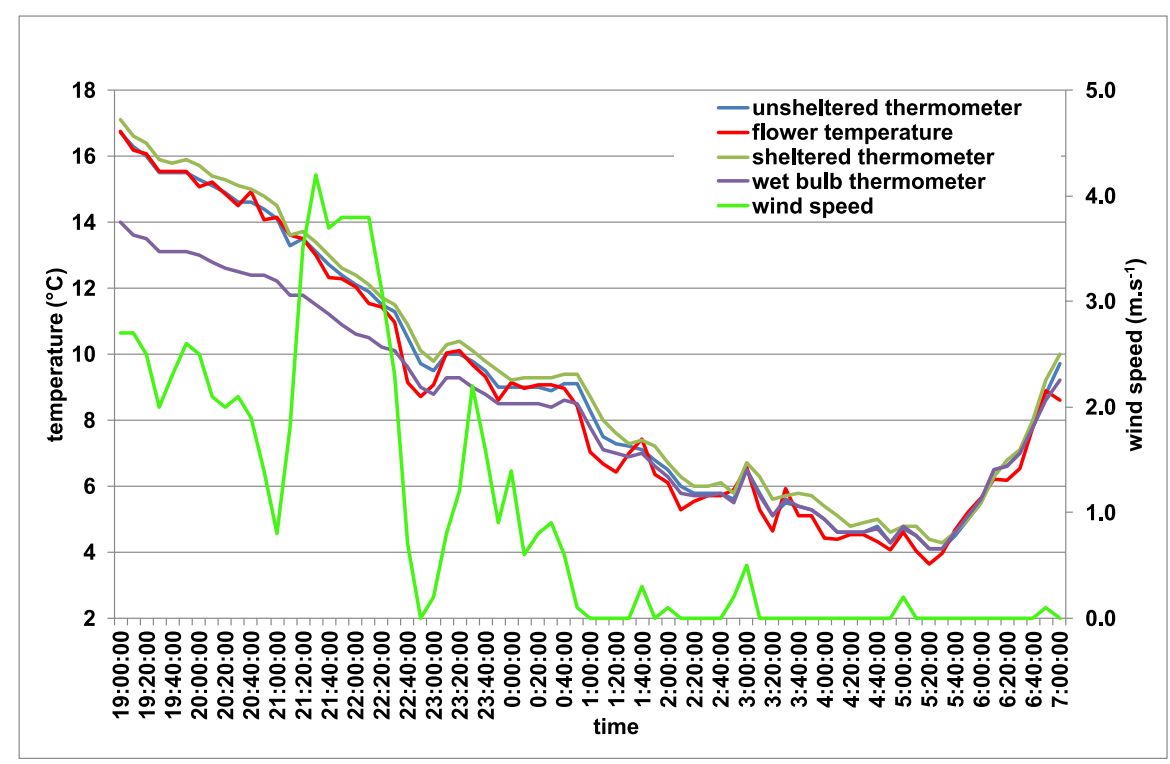

Fig. 5. The courses of air temperatures and the surface temperature of the apricot flowers on the $13-14^{\text {th }}$ of April 2018. 
fact has a significant influence on the success of agro-meteorological models for the prediction of frost on vegetation.

A statistical evaluation of the deviations between the measured minimum air temperatures and the surface temperature is presented in Figs. 6 to 9.

In terms of minimum temperatures, the smallest differences were found using a wet thermometer or unsheltered thermometer. The maximum deviation for the budding vine leaf was $-0.74{ }^{\circ} \mathrm{C}$, in the other investigated/examined cases it reached lower values. The highest deviations were detected between the surface temperature of the plant tissues and the air temperature measured in the radiation shelter in close proximity to the given surface as well as at a nearby meteorological station at a height of $2 \mathrm{~m}$. These temperatures were higher by $0.4-0.8^{\circ} \mathrm{C}$ on average. The highest deviations were observed in the budding leaves of the grapevine, where they reached $1.5^{\circ} \mathrm{C}$. Dětinský and Havlik (1990) state that there is a temperature difference of $0.3{ }^{\circ} \mathrm{C}$ between the cherry blossom surface and the temperature measured in the Stevenson screen at a height of $2 \mathrm{~m}$ during advection at night time; this difference increased to $0.9-1.3^{\circ} \mathrm{C}$ in the case of cherry leaves during the radiation fog, where the vegetation surface is always cooler.

Based on the average deviations determined from all three night measurements (Fig. 9) the best relationship was observed for the unsheltered thermometer, while the wet thermometer usually showed a lower temperature and the sheltered thermometer measured a higher temperature.

The temperature of a plant organ is generally very close to air temperature except in a few specific cases, for example when radiation and vapor pressure deficit are low (Savvides et al., 2013). On the basis of energy balance, unshaded plant parts have a different balance of longwave radiation and eventually latent heat at night. During clear nights, the surface temperature of objects close to the Earth's surface is lower than the ambient air temperature due to longwave radiation (Curtis, 1936). Flowers have few or no stomata and therefore do not exhibit transpirational cooling. At night, when the radiant energy balance is negative, the buds or flowers may be expected to be colder than the atmosphere, and warmer than the air when the sun is shining during the light part of the day (Grace, 2006). They may be similar to the surface temperature of non-living parts of plants (Středa et al., 2015) and significantly different in comparison to the surface temperature of green plant parts. 


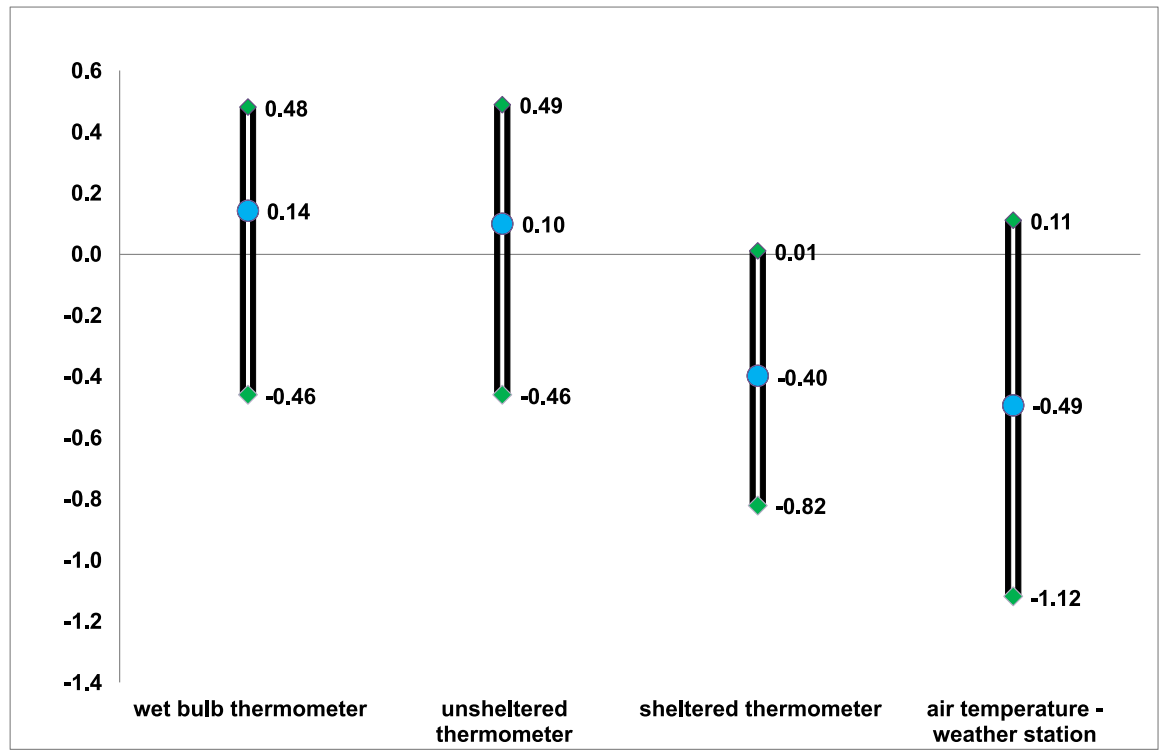

Fig. 6. Average and range of variation between the minimum flower temperatures and the minimum air temperatures.

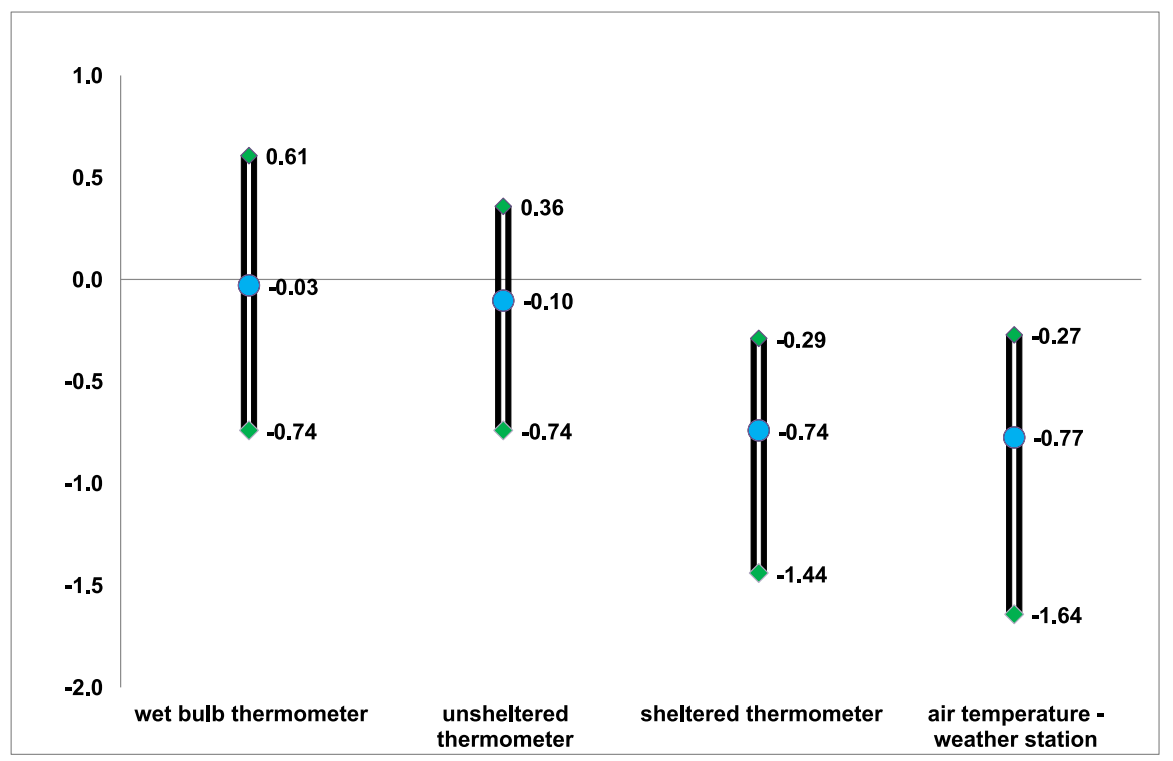

Fig. 7. Average and range of variation between the minimum budding grapevine leaf temperatures and the minimum air temperatures. 


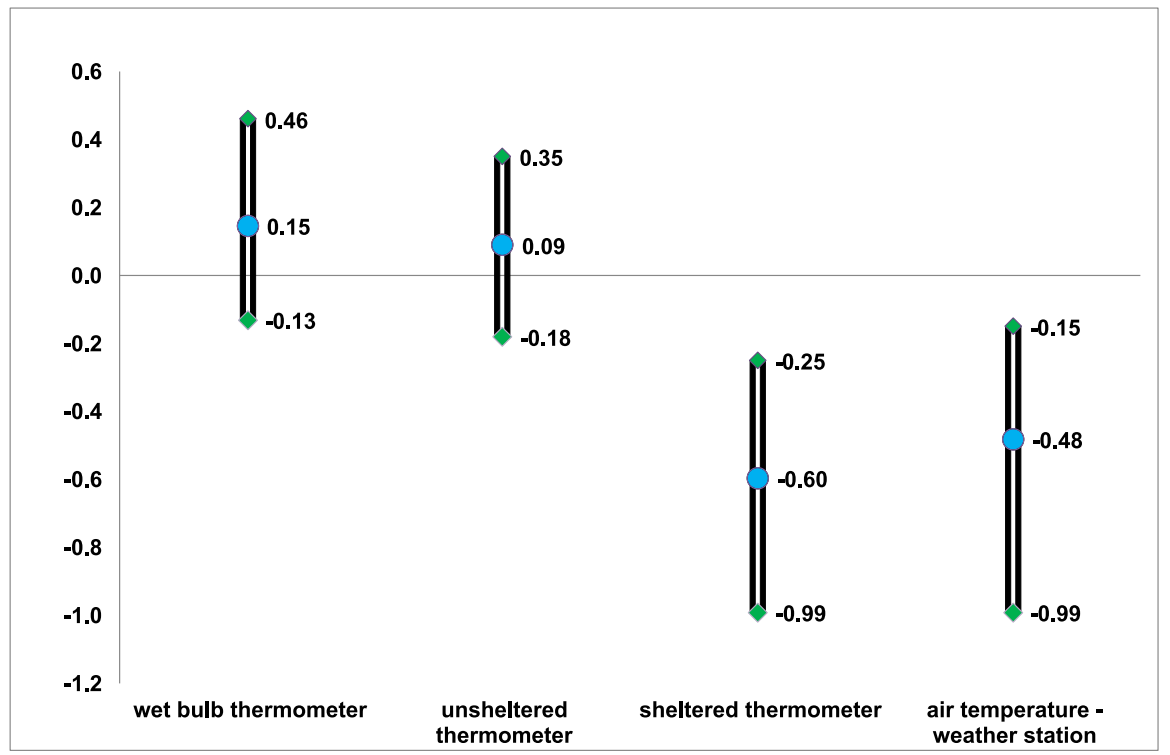

Fig. 8. Average and range of variation between the minimum temperatures of pear fruit and the minimum air temperatures.

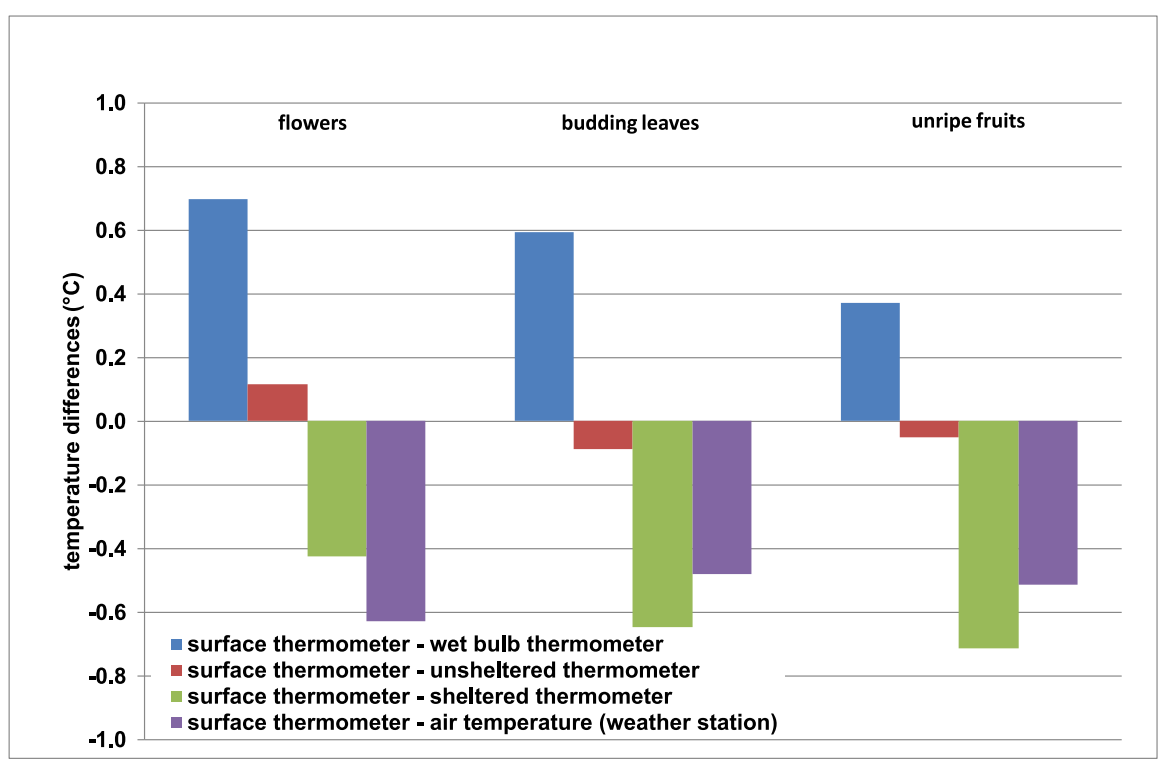

Fig. 9. Average differences between the air temperatures monitored by different methods and the surface temperatures of various plant tissues. 


\section{Conslusion}

The air temperature measured in the standard way (in the Stevenson screen or in the radiation shield) is almost always higher than the temperature of the plant tissue during periods of negative energy balance. A sheltered thermometer always shows higher temperatures throughout the whole night. A wet bulb thermometer only has a good relationship with the temperature of plant tissues during minimum temperatures. This is mainly because the highest relative air humidity is reached at the moment minimum air temperature is reached. A wet thermometer, depending on the relative air humidity, can show a temperature that is even several degrees lower at night. If it were used to control frost protection, it would run prematurely. An unsheltered thermometer, in which the energy balance corresponds approximately to that of the evaluated plant tissues, provides the best relationship with the temperature of the plant tissues.

Acknowledgements. This research was financially supported by projects of the National Agency of Agricultural Research Ministry of Agriculture No. QJ1530181.

\section{References}

Chuchma F., Středová H., Středa T., 2016: Bioindication of climate development on the basis of long-term phenological observation. In MendelNet 2016: Proceedings of International PhD Students Conference. Brno: Mendel University in Brno, 380383.

Curtis O. F., 1936: Leaf temperatures and the cooling of leaves by radiation. Plant Physiology, 11, 2, 343-364, doi: 10.1104/pp.11.2.343.

Dětinský F., Havlík V., 1990: Orchards frost protection with artificial fog (Protimrazová ochrana ovocných sadů umělou mlhou). Práce a studie č. 17, ČHMÚ, 53 p. (in Czech).

Grace J., 2006: The temperature of buds may be higher than you thought. New Phytologist, 170, 1, 1-3, doi : 10.1111/j.1469-8137.2006.01675.x.

Hanan J. J., 1965: Preliminary measurements of flower temperature. Flower Grower's Association Bulletin, 188, 1-4.

Hanan J. J., 1970: Statistical analysis of flower temperatures in the carnation. Journal of the American Society of Horticultural Science, 95, 68-73.

Little L., Eidesen P. B., Müller E., Dickinson K. J. M., Lord J. M., 2016: Leaf and floral heating in cold climates: do sub-Antarctic megaherbs resemble tropical alpine giants? Polar Research, 35, 1-11, doi : 10.3402/polar.v35.26030. 
Morrow C. T., Martsolf J. D., 2004: Mitigating Cold Damage in Horticultural Crops. Crop, Environment and Bioinformatics, 1, 272-296.

Mu J., Li G., Sun S., 2010: Petal Color, Flower Temperature, and Behavior in an Alpine Annual Herb, Gentiana leucomelaena (Gentianaceae). Arctic, Antarctic, and Alpine Research, 42, 2, 219-226, doi : 10.1657/1938-4246-42.2.219.

Savvides A., van Leperen W., Dieleman J. A., Marcelis L. F. M., 2017: Leaf initiation rate is determined by more than just air temperature: considerations for greenhouse climate control and crop modeling. Acta Horticulturae, 1170, 417-424, doi: 10.17660/ActaHortic. 2017.1170.51.

Savvides A., van Leperen W., Dieleman J. A., Marcelis L. F. M., 2013: Meristem temperature substantially deviates from air temperature even in moderate environments: is the magnitude of this deviation species-specific? Plant Cell and Environment, 36, 11, 1950-1960, doi: 10.1111/pce.12101.

Seymour R. S., 1997: Plants that warm themselves. Scientific American, 276, 3, 104-109.

Seymour R. S., Maass E., Bolin J. F., 2009: Floral thermogenesis of three species of Hydnora (Hydnoraceae) in Africa. Annals of Botany, 104,5, 823-832, doi : 10.1093/ aob/mcp168.

Seymour R. S., Schultze-Motel P., 1997: Heat-producing flowers. Endeavour, 21, 3, 125129, doi: 10.1016/S0160-9327(97)80222-0.

Shrestha M., Garcia J. E., Bukovac Z., Dorin A., Dyer A. G., 2018: Pollination in a new climate: Assessing the potential influence of flower temperature variation on insect pollinator behaviour. PLOS ONE, 13, 8, e0200549, doi: 10.1371/journal.pone.02 00549.

Snyder R. L., de Melo-Abreu J. P., 2005: Frost protection: fundamentals, practice and economics, Volume 1. Food and Agriculture Organization of the United Nations, Rome, http://www.fao.org/3/a-y7223e.pdf.

Stehnová E., Středová H., Rožnovský J., Středa T., 2017: Phenological observations and their possible use within the monitoring allergens. In: Public recreation and landscape protection - with nature hand in hand. Brno: Mendel University in Brno, 241-248.

Stehnová E., Středová H., Středa T., 2018: Determination of the time of occurrence of selected allergens with using long-term phenological series. In Public recreation and landscape protection - with nature hand in hand! Brno: Mendel University in Brno, $103-108$.

Středa T., Litschmann T., Středová H., 2015: Relationship between tree bark surface temperature and selected meteorological elements. Contributions to Geophysics and Geodesy, 45, 4, 299-311, doi : 10.1515/congeo-2015-0026.

Středa T., Středová H., Rožnovský J., 2011: Orchards microclimatic specifics. In Bioclimate: Source and Limit of Social Development. Nitra: Slovak Agricultural University, $132-133$.

Wilson C., Grace J., Allen S., Slack F., 1987: Temperature and stature: a study of temperatures in montane vegetation. Functional Ecology, 1, 4, 405-413. 